\title{
Green Synthesis of Zincoxide Nanoparticles from Peganum harmala, and its biological potential against bacteria
}

\author{
Saima Mehar ${ }^{1}$, Sadaf Khoso ${ }^{1}$, Wenwu Qin ${ }^{2}$, Iqra Anam ${ }^{1}$, Anam Iqbal ${ }^{* *}$ and Kanwal Iqbal ${ }^{1 *}$ \\ ${ }^{1}$ Department of Chemistry, Sardar Bahadur Khan Women University Quetta, Pakistan \\ ${ }^{2}$ Key Laboratory of Nonferrous Metal Chemistry and Resources Utilization of Gansu Province and State Key Laboratory of Applied Organic Chemistry, College of \\ Chemistry and Chemical Engineering, Lanzhou University, Lanzhou 730000, P. R. China \\ ${ }^{3}$ Department of Chemistry University of Baluchistan, Quetta 87300, Pakistan
}

\begin{abstract}
Green synthesis of the nanoparticle is becoming popular due to its eco-friendliness, cost effectivity, and possibilities of large scale production. In the present study, Peganum harmala is investigated for their potential to synthesize Zinc oxide nanoparticles. Zinc acetate dihydrate was used as a metal solution and it was mixed with plant extracts under vigorous stirring to obtain NPs. Synthesis of $\mathrm{ZnO}$ NPs was confirmed by change in color of reactant solution from yellow to white. For further confirmation, various characterization techniques were performed to indicate the bonding composition, size, and morphology of as prepared samples. The experimental results indicated that samples were pure $\mathrm{ZnO}$ NPs in nature which was further employed as an antibacterial agent against clinical strains of Listeria monocytogenes, Escherichia coli, Listeria monocytogenes and Salmonella typhi. The analysis to study antibacterial potential was carried out by using well diffusion method which indicated that $\mathrm{ZnO}$ NPs exhibit good potential as a bactericidal.
\end{abstract}

\section{Introduction}

Nanotechnology is incipient as a rapidly emergent field with its synthesis, application, and characterization in science and technology at the nanoscale level for the purpose of manufacturing new materials [1]. Even though there are many directions available for the nanoparticle's synthesis, there is an accumulative need to develop nontoxic, low cost, high-yield and ecologically friendly procedures. So, the biological methodology for the synthesis of nanoparticles becomes vital [2]. Environmentally friendly nanoparticles synthesis procedures need low energy and time expenditure and do not use any toxic chemicals in the synthesis protocols. In these aspects, synthetic methods based on naturally occurring biomaterials offer an alternative means for obtaining these nanoparticles.

Biological molecules have attracted great attention by which they can be controlled and hierarchical assembly and makes them appropriate for the expansion of a consistent and eco-friendly process for synthesis of metal nanoparticle [3].

Biosynthetic approaches are simple and sustainable substitute to attain nanomaterials employing either plants extract or biological microorganisms [4-8]. The combination of nanotechnology and herbal plants gives concept of plant mediated nanoparticle bases drugs. Diverse categories of nanomaterials like copper, titanium [9], magnesium, gold [10], alginate [11] and silver have been reported. It has been reported that angiosperms have the potential for metallic nanoparticles synthesis [12].

Biosynthesized Ag NPs are nowadays utilized in surface Plasmon resonance studies [13,14], antiviral, and anti-HIV studies [15], label-free colorimetric assay to detect enzymatic reactions [16] and antimicrobial materials [17].
In contemporary years for the nanoscale metal synthesis, the biosynthetic method consuming plant extracts have received more attention than the other physical and chemical methods and even than the use of microorganisms, due to the lack of any requirement to maintain disinfected environment. The use of plant extract for the synthesis of nanoparticles could be profitable above other environmentally benign biological processes as it eradicates the intricate process of sustaining cell cultures. A number of plants have been effectively used and reported recently for efficient and rapid extracellular synthesis of different kinds of metallic nanoparticles such as Eclipta prostrata [18], broth extracts of neem [19], Pongamia pinnata [20], Ocimum sanctum [21] and Annona squamosal [22].

Peganum harmala which is commonly called harmal belongs to Zygophyllaceae family [23]. This plant is medicinally important and traditionally has been used for the treatment of various health issues. The main secondary metabolite, which is responsible for many pharmacological potential of $P$. harmala belongs to alkaloid class of compounds [24]. The plant is found to have potential to fight against cancer [25], inflammation [26], bacteria [27] and microbes [28]. Beside many biological activities such as anti-oxidant [29], anti-plasmodium [30], hallucinogenesis [31], anti-tumor [32], anti-virial [33] and antinociceptive potential [34] have also been reported.

${ }^{*}$ Correspondence to: Iqbal A, Department of Chemistry University of Baluchistan, Quetta 87300, Pakistan, E-mail: anamiqbal25@yahoo.com

Iqbal K, Department of Chemistry, Sardar Bahadur Khan Women University Quetta, Pakistan, E-mail: kanwaliqbal98@gmail.com

Key words: Zinc oxide, Nanoparticles, Peganum harmala, antioxidant, antibacterial activity

Received: November 05, 2019; Accepted: December 16, 2019; Published: December 19, 2019 
ZnO Nps are consider to be least toxic [35,36]. These particles have been reported with anti-cancer potential [37]. These particles have capacity to fight against germ positive and germ negative bacterial strain [38]. Thus, ZnO Nps can act as anti-cancer and anti-bacterial agents and can be millstone for advance drug synthesis with great efficiency. In the present investigation, we report the easy synthesis of Zinc oxide nanoparticles by an environmental friendly procedure involving the in situ reduction of $\mathrm{Zn}$ by $P$. harmala extracts and the evaluation of their biological potential as an antioxidant and antibacterial activity

\section{Experimental Section}

\section{Collection and identification of plant}

The whole Plant and seeds of Peganum harmala were collected from Main Gundi, Balochistan region of Pakistan in 2016. Collected samples of the plant were identified by taxonomist, Dr. Rasool Baksh tareen, Dean of Botany Department, University of Balochistan. 10g of sample was deposited in chemistry Lab of Sardar Bahadur Khan Women University Quetta. They were surface cleaned with running tap water, air dried and subjected to electrical grinder. The resulting powder was boiled with distilled water with ration $10: 100$ at $60^{\circ} \mathrm{C}$ for 20-25 min. This extract was filtered through nylon mesh, followed by Millipore filter $(0.45 \mu \mathrm{m})$ were placed in microwave oven for 2 to 3 min., the resulting extract was stored in glass bottles and used for further experiments.

\section{Biosynthesis of $\mathrm{ZnO}$ nanoparticles}

For synthesis of Zinc oxide nanoparticles, aqueous solution (0.02 M) of Zinc acetate dihydrate solution was prepared and used for the synthesis of Zinc nanoparticles. $(10 \mathrm{~mL})$ of $P$. harmala extract was added into $(500 \mathrm{~mL})$ of aqueous solution of $0.02 \mathrm{M}$ zinc acetate at constant stirring for $2 \mathrm{~h}$ at $\left(60{ }^{\circ} \mathrm{C}\right.$ temp) for reduction into $\mathrm{Zn}^{+2}$ ions. The $\mathrm{pH}$ of the solution was kept at 12 . The Reduction of zinc acetate to zinc ions was confirmed by the colour change from yellow to white. White precipitate appeared which indicated synthesis on $\mathrm{ZnO}$ Nps. White Nps were washed with distilled water and methanol solution for purification. The formation of zinc nanoparticles was also confirmed by spectrophotometric determination.

\section{Characterization of $\mathrm{ZnO}$ nanoparticles}

To check phase formation and purity of green synthesized $\mathrm{ZnO}$ Nps, XRD patterns were recorded using powder X-ray diffractometer (Shimadzu-Model, XRD 6000). The analysis was made on scanning mode. Powedered sample of Nps was placed in instrument operating at $40 \mathrm{kV}$ with $30 \mathrm{~mA}$ current. Debye-Scherrer equation was utilized to calculate size of synthesized Nps.

\section{$D=k \lambda / \beta \theta \cos \quad$ Where $\lambda$ is $\mathrm{x}$ ray wavelength which was $1.5418 \AA$.}

Sample of ZnO Nps was placed on specimen stubs. To prevent charging, sample was coated in a sputter coater. Sample was examined under SEM (HITACH, Model S-3400N). Reaction mixture of green synthesis of Nps was placed in centrifuge at speed $45 \mathrm{rmp}$ for 40 mins. Centrifuge enable the separation of solids pellets of Nps which was dissolved in distilled water followed by filtration. Small quantity of this dissolved Nps filtrate was used for SEM and EDX analysis.

Structural features of plant mediated nanoparticles were characterized by advance techniques such as FTIR, EDX, XRD and SEM. All analysis was made in triplicates. Obtained data were analyzed by origin software.

\section{Bacterial Culture preparation}

Bacterial species Listeria monocytogenes, Escherichia coli, Listeria monocytogenes and Salmonella typhi were collected USA. Microbiology laboratory Quaid-e-Azam University Islamabad Pakistan. All bacterial strain were provided with ager solution along $6 \mathrm{~g}$ of Trypton Soy Broth at $121{ }^{\circ} \mathrm{C}$ for 20 minute and then for incubation period of 24 hours.

\section{Antibacterial assays}

The antibacterial assays were done on human pathogenic Escherichia coli and Staphylococcus aureus, Listeria monocytogenes and Salmonella typhi by standard well diffusion method. Antibacterial activities of $\mathrm{ZnO}$ Nps were evaluated against highly multiple drug resistant bacterial strains. Well diffusion method was carried out to evaluate the antibacterial activity of $\mathrm{ZnO} \mathrm{Nps}$. For this $(10 \mathrm{mg} / \mathrm{ml})$ $\mathrm{ZnO}$ Nps dissolved in DMSO. The inoculums of bacterial strains were prepared by growing a single colony for overnight in nutrient broth. Petri plates containing media were swabbed with bacterial strains by using cotton buds wells were made in nutrient agar $0.1 \mathrm{M} \mathrm{ZnS}$ and aqueous plant extract (positive control), DMSO (negative control) and $20 \mathrm{ml}$ of each synthesized- $\mathrm{ZnO} \mathrm{Nps}$ were added in wells. Petri plates were incubated for 24 hours at $37{ }^{\circ} \mathrm{C}$ and the inhibition zone was measured. This experiment repeated thrice.

\section{Antioxidant activity}

The DPPH free radical scavenging assay was conducted based on the method of Samiullah, et al. [38] with slight modification. The procedure involves mixing of each sample with DPPH solution with different concentration followed by spectrophotometric analysis. The solution of crude methanolic extract of varying concentration 0.02 , $0.04,0.06,0.08$, and $0.1 \mathrm{mg} / \mathrm{ml}$ was prepared in solvent. Similarly, all sample of varying concentration with NPs were prepared. Freshly prepared $1 \mathrm{ml}$ of $0.1 \mathrm{mM}$ DPPH solution was added with $1.5 \mathrm{ml}$ of all samples including crude methanolic extract of plant and $\mathrm{ZnO}$ Nps. Each sample mixture was kept in dark for 25 minutes at $37^{\circ} \mathrm{C}$ followed by UV. V is absorbance at $517 \mathrm{~nm}$. Solution of Ascorbic acid of same concentration ranging from $(0.02-0.1 \mathrm{mg} / \mathrm{ml})$ was use as control. The percentage of inhibition or scavenging of free radicals was determined by the following formula:

$$
\begin{aligned}
& \text { Percentage of radical capturing activity }=\left(A b s_{(\text {control) }}-A b s_{(\text {sample })}\right) / \\
& A b s_{(\text {control) }} \times 100 \%
\end{aligned}
$$

\section{Results and discussion}

Plants with herbal potential are safer mean for treatment. Different phytochemicals which are present in plants concentrated on extraction, so plant extract efficiency increases and can lead for new effective drugs. The detailed study on biosynthesis of zinc oxide nanoparticles by natural plants extract of Peganum harmala were carried out and documented in this work. The aqueous zinc ions were reduced to zinc oxide nanoparticles when added to natural plant extract of Peganum harmala. It was observed that the color of the solution turned from (yellow to white during 1-48 h). of the reaction, which showed the formation of $\mathrm{ZnO}$ nanoparticles.

FTIR spectroscopy was used to confirm the surface groups of the nanoparticles qualitatively with spectra recorded by a Perkin-Elmer model FTIR spectrophotometer. The mean particle diameter of zinc nanoparticles was calculated from the XRD pattern rendering to the line width of the plane, refraction peak using Debye-Scherrer equation. SEM analysis was carried out to understand the topology and the 
size of the $\mathrm{ZnO}-\mathrm{NPs}$, which showed the synthesis of higher density polydispersed spherical ZnO-NPs of spherical shape of $39.94 \mathrm{~nm}$ sizes. While the presence of metals in the sample was analysed by EDX.

\section{FTIR analysis of P. harmala mediated $\mathrm{ZnO}$ Nps}

The FTIR spectra of aqueous zinc oxide nanoparticles prepared from the $P$. harmala extract (Figure 1) show transmittance peaks at $3450 \mathrm{~cm}^{-1}$. This peak corresponds to stretching bands for $-\mathrm{OH}$ group. A peak was observed at $3000 \mathrm{~cm}^{-1}$ which indicate the presence of $\mathrm{C}-\mathrm{H}$ bond. Stretching vibration for C-C bond was observed with peak 1350 $\mathrm{cm}^{-1}$. Another peak was also notice which was at $1010 \mathrm{~cm}^{-1}$. This peak was due to $\mathrm{C}-\mathrm{O}$ functional group.

\section{XRD analysis of $P$. harmala mediated $\mathrm{ZnO}$ Nps}

XRD analysis showed distinct diffraction peaks at $31.75,34.54$, $36.21,47.67,56.66,62.76$ and 68.16 corresponding to (100), (002), (101), (102), (110), (103), (200), (112) and (201).

The structure of $\mathrm{ZnO}$ Nps suggested by these observation is hexagonal wurtzite. The obtained data was matched with the database of Joint Committee on Powder Diffraction Standards (JCPDS) file No. 36-1451. The average grain size of the zinc oxide nanoparticles formed in the bio reduction method was determined to be $39.94 \mathrm{~nm}$ by using $D$ $=k \lambda / \beta \theta \cos$ equation (Figure 2 )

\section{FESEM of the synthesized ZnO Nps}

SEM analysis of the synthesized $\mathrm{ZnO}$ Nps were carried out to determine the morphology of synthesized $\mathrm{ZnO}$ nanoparticles. For the SEM studies, dried sample of reaction mixture was used. A representative SEM micrograph (Figure 3) of synthesized nanoparticles showed that they have spherical structures with a size of $39.94 \mathrm{~nm}$

\section{EDX result for ZnO Nps synthesized by extract of $P$. harmala}

The presence of metals in the sample was analyzed by EDS.The energy-dispersive X-ray (XRD) attachment present with the SEM was known to provide information on the chemical analysis of the fields being investigated or the composition at specific locations (spot EDX). Figure 4 shows the spectra obtained from $\mathrm{ZnO}$ Nps synthesized from $P$. harmala plant. The spectra shows $\mathrm{Zn}$ has absorption peaks approximately at $1.32 \mathrm{keV}, 8.92 \mathrm{keV}$ and $9.5 \mathrm{keV}$ while $\mathrm{O}$ has optical absorption peaks at $0.59 \mathrm{keV}$.

The data obtained for $\mathrm{ZnO}$ Nps synthesized by plant extract of $P$. harmala is shown in Table 1, which shows presences of $29.39 \%$ oxygen element and 70.61\% Zinc element (Figure 5 and Figure 6).

\section{Phytochemical analysis}

Phytochemical studies was carried out with aim to point out total phenolic content (TPC), total flavonoids content (TFC) and total alcoholic content (TAC). Analysis was made on crude extract as well as on plant mediated zinc oxide Nps. Higher content of flavonoids, alkaloids and phenol was observed in $\mathrm{ZnO}$ Nps as compare to crude extract (Table 2). Graphical representation shows flavonoids are present in high concentration as compare to alcoholic and phenolic contents.

\section{Antioxidant analysis}

Anti-oxidant analysis was conducted by total radical scavenging potential (TRP) and DPPH assay. Plant extract and plant mediated Nps both have anti-oxidant potential but crude extract is found to be more effective as compare to Nps derived from it (Table 3).

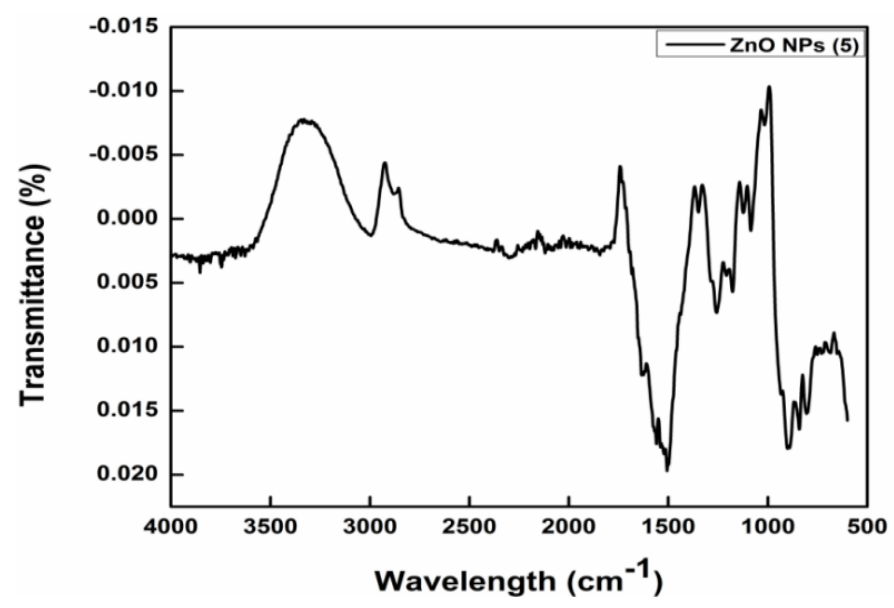

Figure 1. FTR spectrum of the Nps

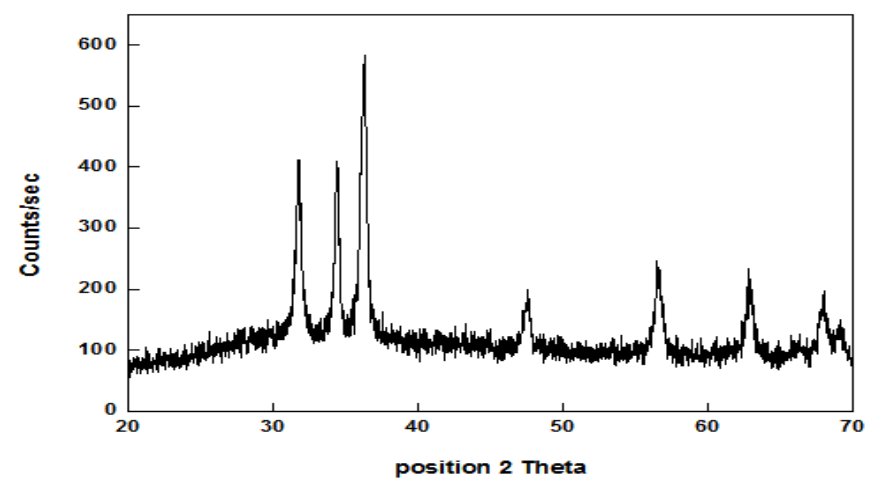

Figure 2. XRD spectra of plant mediated $\mathrm{ZnO} \mathrm{Nps}$

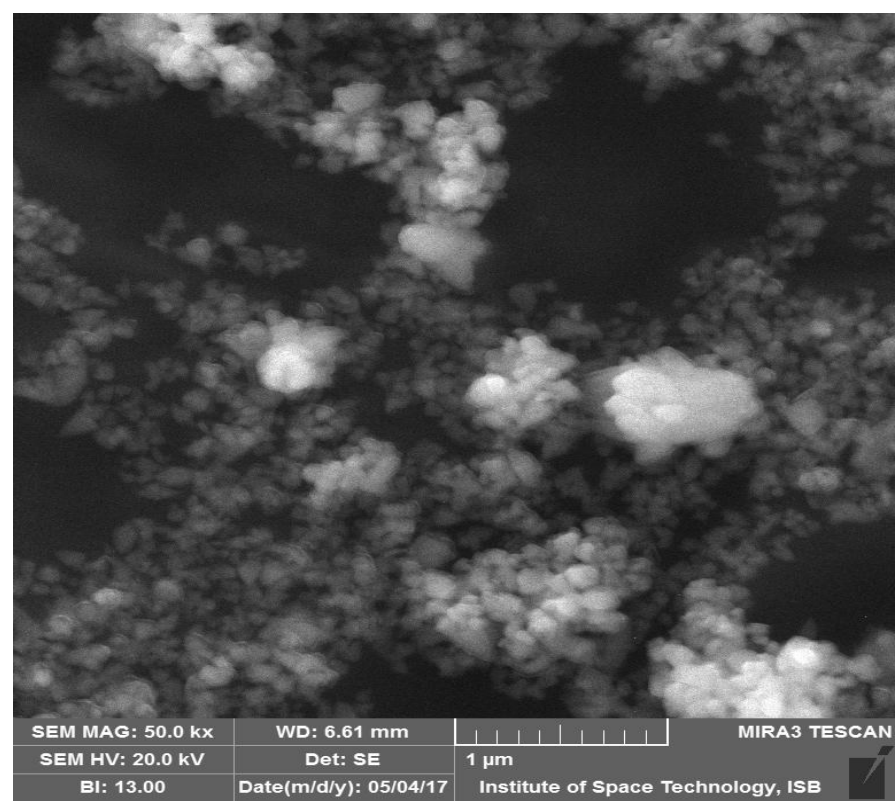

Figure 3. SEM result for green synthesized Nps

\section{Antibacterial analysis}

Antibacterial activity of zinc nanoparticles were investigated against four bacterial strain S. aureous, E. coli, L. monocytogenes and S. typhi expressed in Table 4. Plant mediated $\mathrm{ZnO}$ Nps are found to be more 


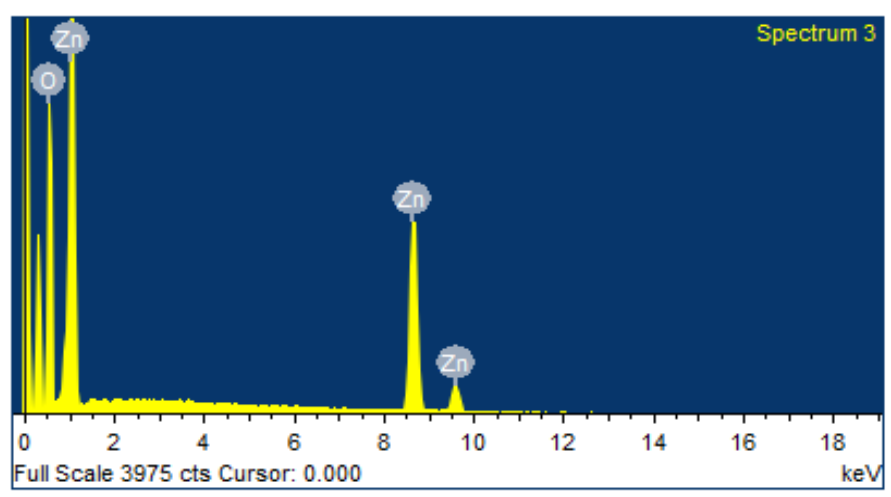

Figure 4. EXD spectra of $\mathrm{ZnO} \mathrm{Nps}$

Phytochemical analysis

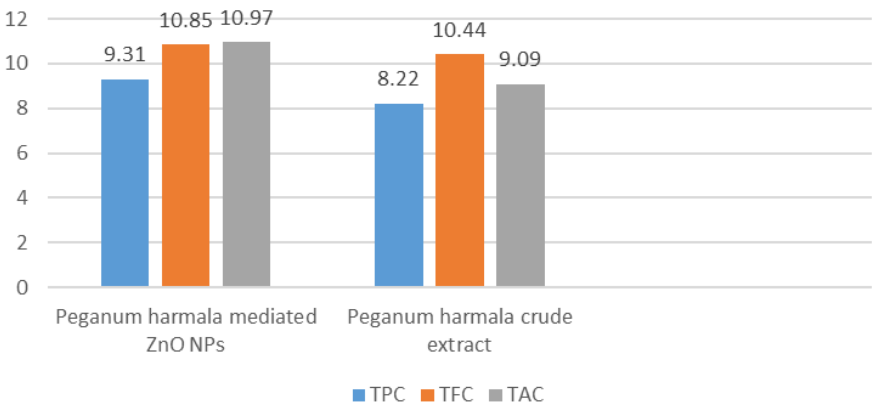

Figure 5. Comparison of phytochemical b/w ZnO Nps and crude extract

\section{Anti-oxidant assay}

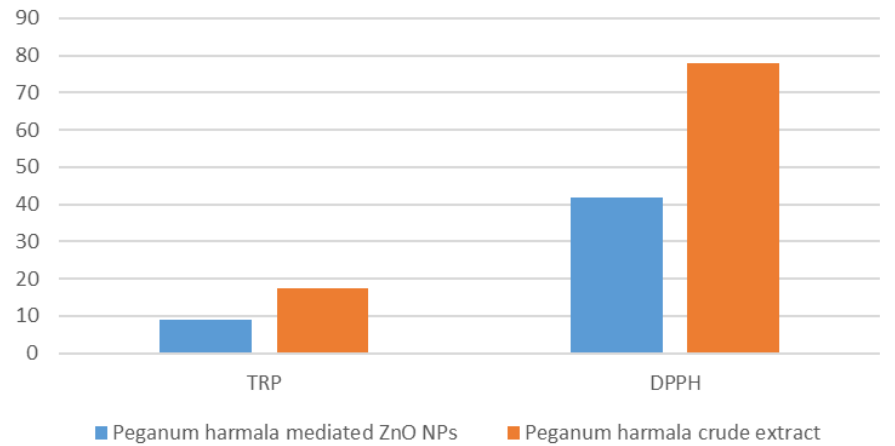

Figure 6. Graphical representation of TRP and DPPH assay of Nps and crude extract of P. harmala

Table 1. Data of composition for P. harmala mediated $\mathrm{ZnO}$ NPs

\begin{tabular}{|c|c|c|}
\hline Element & Weight\% & Atomic\% \\
\hline O K & 29.39 & 62.98 \\
\hline Zn K & 70.61 & 37.02 \\
\hline Totals & 100.00 & \\
\hline
\end{tabular}

Table 2. Phytochemical analysis of crude extract and Nps

\begin{tabular}{|l|c|c|c|}
\hline Plant Name & TPC & TFC & TAC \\
\hline P. harmala mediated $\mathrm{ZnO} \mathrm{Nps}$ & 9.31 & 10.85 & 10.97 \\
\hline P. harmala crude extract & 8.22 & 10.44 & 9.09 \\
\hline
\end{tabular}

Table 3. Anti-Oxidant Assay of crude extract and $\mathrm{ZnO}$ Nps

\begin{tabular}{|l|c|c|}
\hline Plant Name & TRP & DPPH \\
\hline P. harmala mediated $\mathrm{ZnO} \mathrm{NPs}$ & 9.09 & 41.91 \\
\hline P. harmala crude extract & 17.41 & 77.97 \\
\hline
\end{tabular}

Table 4. Antibacterial assay of $P$. harmala mediated $\mathrm{ZnO}$ Nps and its crude extract

\begin{tabular}{|c|c|c|}
\hline Bacteria & ZnO Nps & Plants Extracts \\
\hline Staphylococuss aureous & $17 \mathrm{~mm}$ & $16 \mathrm{~mm}$ \\
\hline Listeria monocytogenes & $13 \mathrm{~mm}$ & $12 \mathrm{~mm}$ \\
\hline Escherichia coli & $10 \mathrm{~mm}$ & $14 \mathrm{~mm}$ \\
\hline Salmonella typhi & $10 \mathrm{~mm}$ & $11 \mathrm{~mm}$ \\
\hline
\end{tabular}

effective against $S$. aureous $(17 \mathrm{~mm})$. The response of $\mathrm{ZnO}$ nanoparticles against Listeria monocytogenes $(10 \mathrm{~mm})$ was also satisfactory. However lowest response was observed against E. coli $(10 \mathrm{~mm})$ and S. typhi $(10 \mathrm{~mm})$ with minimum zone of inhibition.

\section{Conclusion}

Nano-biotechnology signifies a new epoch of ground-breaking approach to develop and test modern drug formulations established on biosynthesized nanoparticles with diverse biological activities such as antioxidant, antibacterial and anticancer properties The zinc nanoparticles have been produced by $P$. harmala (plant extracts) a medicinally significant plant, which is an economical, efficient and eco-friendly process. UV-vis spectrophotometer, XRD, SEM and EXD techniques have confirmed the reduction of zinc acetate to zinc nanoparticles. Basic composition of $\mathrm{ZnO} N$ ps were $29.39 \%$ with regard of oxygen element and $70.61 \%$ with regard of Zinc. Comparative phytochemical study of plant mediated $\mathrm{ZnO}$ Nps and plant's crude extract showed higher content of TAC, TFC and TPC. The antioxidant activity was determined by DPPH assay showed good activity. The zones of inhibition were formed in the antibacterial screening test indicated, that the $\mathrm{ZnO}$ nanoparticles synthesized in this process has the efficient antibacterial activity against pathogenic bacteria. The biologically synthesized silver nanoparticles could be of immense use in medical field for their efficient antibacterial and antioxidant function.

\section{References}

1. Albrecht MA, Evans CW, Raston CL (2006) Green chemistry and the health implications of nanoparticles. Green Chem 8: 417-432.

2. Murali S, A Ahmad, MI Khan, R Kumar (2003) Biosynthesis of metal nanoparticles using fungi and actinomycete. Curr Sci 85: 162-170.

3. Nilesh C, Sharma S, Sahi J, Sudipnath, Parsons JG, et al. (2007) Synthesis of Plant-Mediated Gold Nanoparticles and Catalytic Role of Biomatrix-Embedded Nanomaterials. EnvironSci Technol 47: 5137-5142.

4. Chandran SP, Chaudhary M, Pasricha R, Ahmad A, Sastry M (2006) Synthesis of gold nanotriangles and silver nanoparticles using Aloe vera plant extract. Biotechnol Prog 22: $577-583$.

5. Gardea Torresdey JL, Parsons JG, Gomez E, Peralta-Videa J, Troiani HE, et al. (2002) Formation and growth of Au Nanoparticles inside live Alfalfa plants. Nano Lett 2: 397 401.

6. Joerger R, Klaus T, Granqvist CG (2000) Biologically produced silver-carbon composite materials for optically functional thin-film coatings. Adv Mater 12: 407-409.

7. Shankar SS, Ahmad A, Pasricha R, Sastry M (2003a) Bioreduction of chloroaurate ions by geranium leaves and its endophytic fungus yields gold nanoparticles of different shapes. J Mater Chem 13: 1822-1826.

8. Shankar SS, Ahmad A, Sastry M (2003b) Geranium leaf assisted biosynthesis of silver nanoparticles. Biotechnol Prog 19:1627-1631.

9. Retchkiman-Schabes PS, Canizal G, Becerra-Herrera R, Zorrilla C, Liu HB, et al (2006) Biosynthesis and characterization of Ti/Ni bimetallic nanoparticles. Opt Mater 29: 95-99.

10. Gu H, Ho PL, Tong E, Wang L, Xu B (2003) Presenting vancomycin on nanoparticles to enhance antimicrobial activities. Nano Lett 3: 1261-1263.

11. Ahmad Z, Pandey R, Sharma S, Khuller GK (2005) Alginate nanoparticles as antituberculosis drug carriers: formulation development, pharmacokinetics and therapeutic potential. Ind J Chest Dis Allied Sci 48: 171-176. 
12. Song JY, Kim BS (2009) Rapid biological synthesis of silver nanoparticles using plant leaf extracts. Bioprocess Biosyst Eng 32:79-84.

13. Turney K, Drake TJ, Smith JE, TanW, Harriso WW (2004) Functionalized nanoparticles for liquid atmospheric pressure matrix-assisted laser desorption/ionization peptide analysis. Rapid Commun Mass Spectrom 18:2367-2374.

14. Kundu S, Mandal M, Ghosh SK, Pal T (2004) Photochemical deposition of SERS active silver nanoparticles on silica gel. J Photochem Photobiol A Chem 162:625-663.

15. Elechiguerra JL, Burt JL, Morones JR, Camacho-Bragado A, Gao X, et al. (2005) Interaction of silver nanoparticles with HIV-1. J Nanobiotechnol 29:3-6.

16. Wei H, Chen C, Han B, Wang E (2008) Enzyme colorimetric assay using unmodified silver nanoparticles. Anal Chem 80:7051-7055.

17. Duran N, Marcato PD, Alves OL, Souza GI, Esposito E (2005) Mechanistic aspects of biosynthesis of silver nanoparticles by several Fusarium oxysporum strains. $J$ Nanobiotechnol 13:3-8.

18. Rajkumar G, Rahuman AA (2011) Larvicidal activity of synthesized silver nanoparticles using Eclipta prostrata leaf extract against filariasis and malaria vector. Acta Trop 118 196-203.

19. Shankar SS, Rai A, Ahmad A, Sastry M (2004) Rapid synthesis of Au, Ag, and bimetallic Au core Ag shell nanoparticles using Neem (Azadirachta indica) leaf broth. $J$ Colloid Interface Sci 275: 496-502.

20. Raut RW, Niranjan S, Kolekar Jaya R, Lakkakula Vijay D, Mendhulkar SB, et al. (2010) Extracellular synthesis of silver nanoparticles using dried leaves of Pongamia pinnata (L) Pierre. Nano Micro Lett 2: 106-113.

21. Ahmad N, Sharma S, Alam MK, Singh VN, Shamsi SF, et al. (2010) Rapid synthesis of silver nanoparticles using dried medicinal plant of basil. Colloids Surf B Biointerfaces 81:81-86.

22. Naresh Kumar A, Murugan K, Rejeeth C, Madhiyazhagan P, Barnard DR (2011) Green synthesis of silver nanoparticles for the control of mosquito vectors of malaria, filariasis, and dengue. Vector-Borne Zoo Dis 12: 3.

23. Moloudizargari M, Mikaili P, Aghajanshakeri S, Asghari MH, Shayegh J (2013) Pharmacological and therapeutic effects of Peganum harmala and its main alkaloids. Pharmacognosy reviews 7: 199-212.

24. Berrougui H, Martín-Cordero C, Khalil A, Hmamouchi M, Ettaib A, et al. (2006) Vasorelaxant effects of harmine and harmaline extracted from Peganum harmala $\mathrm{L}$ seed's in isolated rat aorta. Pharmacological research $54: 150-157$.
25. Lamchouri F, Zemzami M, Jossang A, Abdellatif A, Israili Z H, et al. (2013) Cytotoxicity of alkaloids isolated from Peganum harmala seeds. Pak J Pharm Sci 26: 699-706.

26. Kumar MR, Joshi SD, Kulkarni VH, Savant C (2015) Phytochemical screening and evaluation of analgesic, anti-antiinflammatory activities of Peganum harmala Linn seeds in rodents. J Pharm Sci 5: 052-055.

27. Shahverdi AR, Monsef-Esfahani HR, Nickavar B, Bitarafan L, Khodaee S, et al. (2005) Antimicrobial activity and main chemical composition of two smoke condensates from Peganum harmala seeds. Zeitschrift für Naturforschung 60: 707-710.

28. Dickson RA, Houghton PJ, Hylands PJ, Gibbons S (2006) Antimicrobial, resistancemodifying effects, antioxidant and free radical scavenging activities of Mezoneuron benthamianum Baill, Securinega virosa Roxb \& Wlld and Microglossa pyrifolia Lam. Phytotherapy Research 20: 41-45.

29. Astulla K, Zaima Y, Matsuno Y, Hirasawa W, Ekasari A, et al. (2008) Alkaloids from the seeds of Peganum harmala showing antiplasmodial and vasorelaxant activities. Journal of Natural Medicines 62:470-472.

30. Hearn EO, Molliver ME (1993) Degeneration of Purkinje cells in parasagittal zones of the cerebellar vermis after treatment with ibogaine or harmaline. Neuroscience 55:303310 .

31. Hayet E, Maha M, Mata M, Mighri Z, Laurent G, et al. (2010) Biological activities of Peganum harmala leaves. Afr J biotech 9: 8199-8205.

32. Farouk L, Laroubi A, Aboufatima R, Benharref A, Chait A (2009) Antinociceptive activity of various extracts of Peganum harmala $\mathrm{L}$ and possible mechanism of action. IJPT 8: 29-35.

33. Zhang Y, Nayak TR, Hong H, Cai W (2013) Biomedical applications of zinc oxide nanomaterials. Curr Mol Med 13: 1633-1645

34. Rasmussen JW, Martinez E, Louka P, Wingett DG (2010) Zinc oxide nanoparticles for selective destruction of tumor cells and potential for drug delivery applications. Expert Opin Drug Deliv 7: 1063-1077.

35. Azam A, Ahmed AS, Oves M, Khan MS, Habib SS, et al. (2012) Antimicrobial activity of metal oxide nanoparticles against Gram-positive and Gram-negative bacteria: a comparative study. Int J Nanomed 7: 6003.

36. Samiullah F, Alam S, Aslam RB, Tareen A, Khan N, et al. (2017) Buzdar, Determination of Chemical Composition, Total Phenolic Content and Antioxidant Activity of Xylanthemum Macropodum. J Chem Soc Pak 39: 83-91.

Copyright: (C2019 Mehar S. This is an open-access article distributed under the terms of the Creative Commons Attribution License, which permits unrestricted use, distribution, and reproduction in any medium, provided the original author and source are credited. 